\title{
Time is Money: Disentangling Higher Education Cost- Sharing and Commodification through Deferred Graduate Retirement
}

\begin{abstract}
Current higher education policy debates in Europe are increasingly focusing on raising the share of private funding. To date, policy proposals have centred on a relatively small number of alternatives, namely full public funding, tuition fees, either up-front or delayed and income-contingent, or a surtax on graduate incomes. Here, I present an alternative that, to my knowledge, has not been suggested previously, but sidesteps some important objections against other forms of private contributions. The basic idea explored here is to increase the statutory retirement age for higher education graduates relative to nongraduates. In principle, the resulting decrease in future public pension liabilities can be converted into increased funds for present spending on higher education. In this first discussion of the above proposal I consider important caveats, perform an order-ofmagnitude estimate of whether the financial implications of Deferred Graduate Retirement (DGR) are comparable to those of tuition fees, and discuss advantages and disadvantages compared to more established policy options. I conclude that, at least in the continental European context, DGR promises a number of economically and politically desirable properties compared to established alternatives, and deserves more serious investigation.
\end{abstract}

\section{Keywords}

higher education, fees, funding, access, retirement 


\section{Introduction}

Cost sharing is 'both a statement of fact - that is, that the costs of higher education are shared among stakeholders - and also a reference to a policy shift of some of these costs from a predominant (sometimes a virtually exclusive) reliance on governments' (Altbach et al, 2009, 73). To date, such debates have centered exclusively on a relatively small number of policy instruments, namely full public funding, tuition fees, either up-front or delayed and income-contingent, or a surtax on graduate incomes.

Here, I show that alternative schemes are conceivable that could sidestep some important objections against other forms of private contributions. This includes both the 'the devilishly difficult' (Johnstone, 2000, 1) challenge of not discouraging participation among less advantaged students, and fundamental concerns regarding the compatibility of students-as-customers with the core values of higher education (Tilak, 2009; Williams, 2014). Indeed, a rejection of commodification of education and an ensuing commercialization of the HE sector is one of the main objections to cost-sharing, even though these issues are distinct both in theory and - as the present contribution aims to show - potentially even in practice.

One possibility, explored here, is to raise the statutory retirement age for higher education (HE) graduates relative to non-graduates. In principle, the decrease in public pension liabilities is convertible into increased present spending on HE. In the following, such a scheme is termed Deferred Graduate Retirement (DGR). This idea is most relevant where public pensions are substantial, and the private contribution to HE funding is not already comparable to public funding, implying a focus on OECD member countries, especially continental European ones. These provide the most fertile ground for DGR with their relatively generous publicly-funded pensions, and limited existing reliance on tuition fees (and large resistance to them).

Strictly economically, DGR may theoretically be approximated by a graduate tax of appropriate design: reduced pension at constant contributions have a pure accounting equivalent in increased contributions at constant benefits. However, such a view is too limited. For one, in terms of the economic implications of mandating one or the other 
within a framework of endogeneous decisions regarding labour supply, for example. But also in that such a limited view ignores real-life cognitive and behavioural effects. In relation to HE participation, manifest behaviour is well-documented to deviate from strictly economic rationality. This has been noted with respect to mobility (Wakeling and Jefferies, 2013), take-up of financial aid or the repayment schedule of student debt (Chowdry et al., 2012), and the 'haphazard post-secondary choice process' in general (Scott-Clayton, 2013, 75). In his study of decision-making among HE applicants, Usher (2010) found 'there was not a single case of a student being able to show in concrete terms that they had appraised their chosen HE options in terms of both costs and benefits' (p 69). Policy-making with respect to HE funding is likewise 'less the result of rational analyses and more the outcome of negotiation among stakeholders with competing interests' (Marcucci, 2013, 9). It matters how issues are framed, communicated, and justified (Usher, 2010). Accordingly, policies that are equivalent in accounting terms can interact quite differently with perceptions, attitudes, and actual participation decisions.

Naturally, there is no empirical evidence yet on how prospective HE entrants perceive and respond to the idea of DGR. However, given well-known general cognitive biases (e.g. 'sticker price shock', or 'hyperbolic discounting') it seems highly likely that DGR will have a different effect on HE participation behaviour than fees or a graduate tax. To make the case why DGR might actually be preferable, it is therefore necessary to discuss the issue in terms of HE policy, not of formal public welfare economics. In a different context, the financial feasibility of the policy would be a necessary 'box to tick', but the potential effects of different HE financing instruments on aggregate welfare, human capital investment, or labour supply, say, would take centre stage. The modest present aim is merely to examine whether any of the likely effects are so obviously undesirable as to eliminate DGR from further consideration.

The presentation is organised as follows. Section 2 outlines major lines of criticism of existing cost-sharing instruments, in order to anticipate the standards that DGR will be measured against. The characteristics of the DGR scheme are then outlined and explained in Section 3, in particular the way it represents an increase in private contributions that is only weakly linked to HE commercialization, if at all. Section 4 provides a rough order-of-
Commented [PN1]: Reference missing

Commented [2]: Reply to Poulton, Nicholas (05/04/2017, 14:03): "..."

added

Commented [PN3]: Reference missing

Commented [4]: Reply to Poulton, Nicholas (05/04/2017, 14:03): "..."

added 
magnitude calculation to establish the potential financial appropriateness of the scheme, and points to possible directions for a more detailed economic analysis. I conclude by discussing in Section 5 the expected effects of DGR on the HE system and by speculating on the scheme's policy implications.

\section{Desiderata for Cost-Sharing Instruments}

Academic and policy discourses focus on a very limited number of HE financing instruments in varying the share of private contributions: full public funding, up-front fees, delayed income-contingent fees, and a graduate tax. A succinct overview of the defining characteristics of these is provided by Johnstone (2004), for example.

In practice, fees coexist with subsidies and a mixture of grants and loans, which in turn might be subject to income-contingent repayment. The boundaries between instruments may be blurred, depending on the precise modalities, with many student loan schemes including a 'hidden grant' component (Shen and Ziderman, 2008), for instance.

Not least because these policies rarely exist in their 'pure' form, rather than retrace the arguments voiced for and against individual instruments and attempt to arbitrate between them, I leap straight to extracting desiderata for an 'ideal' cost-sharing instrument. These are requirements implicitly or explicitly appealed to in debates on cost-sharing and thereby provide the criteria against which DGR can be assessed.

Note that students' living expenses are not considered here. Such indirect costs of HE are arguably the largest cost factor, and accordingly there is a case for student loans even in the absence of fees, and for grants for disadvantaged groups. However, universal unconditional grants covering the full living cost for HE students would clearly be socially regressive. Their complete absence from serious policy discussion shows that there is little question that, in principle, living expenses are a private cost. In this sense, the issue of living expenses is outside the boundary of disagreement about the appropriate amount of cost-sharing in HE that DGR seeks to address. 


\subsection{Equality of opportunity: Student choice unconstrained by socio-economic status}

It is generally agreed that fees can only be justified in the presence of student loans and grants, at least for those otherwise least able to afford enrolment. This includes fee proponents operating within a (neo-)classical paradigm (because optimal HE investment an absence of liquidity constraints) even if in practice the first part of the 'high fees, high aid' formula has been implemented much more readily than the second (Hossler et al., 1997).

Even under conditions where fees are a financially sound investment, they may represent a psychological obstacle for potential students, and this effect may disproportionally affect those from low socio-economic status (SES) backgrounds. Complex cultural factors lie behind the low participation of disadvantaged groups in HE (Biffl and Issac, 2002). Scholarships and grants have to over-compensate fees in order to counter the psychological barrier to enrolment created by fees (Vossensteyn, 1999). Indeed, disadvantaged students are known to be more price-averse, more debt-averse, and are less confident they will successfully graduate (Asplund at al, 2008), even if some of these characteristics are shared by marginal potential entrants generally, independently of social background (Davies et al., 2009; Mangan et al., 2010).

These observations are only superficially contradicted by studies showing surprisingly little impact of fees on HE demand (Wakeling and Jefferies; 2013), including among the disadvantaged (Harrison, 2011; Whitty et al. 2015). The deterrent effect may be underestimated if the potential endogeneity of tuition fees is ignored (Neill, 2009). Moreover, disadvantaged students may be negatively affected by fees in terms of compromising their choice of institution or subject, rather than their overall decision to study (Hutchings, 2003; Callender and Jackson, 2005, 2008; Usher, 2010). 


\subsection{Pooling the risk of inability to pay}

Even deferred fees may unduly deter potential entrants from enrolment if they question their ability to afford the charge even after graduation. Taking the ability to pay into account motivates income-contingent repayment, allowing for fluctuations in income and periods of hardship (Barr, 2004). Graduate tax schemes and income-contingent loans both share this characteristic, justifiable both on economic and social justice grounds. Indeed, insurance against uncertainty is a welfare value as such, especially with respect to education (Barr, 2001).

Income-contingent repayment implies a risk of default. Some graduates may leave the labour force, or not achieve higher incomes than the average non-graduate. This risk premium is non-negligible, estimated to contribute between 2.5 and 3 points to the interest rate on the loan (Gerard and Vandenberghe, 2007). This premium is either pooled among graduates (if priced into repayments) or shared with the public (given an interest-rate subsidy). Risk pooling is critical because, while the pattern that graduates enjoy higher average incomes is highly robust, the variation in individual incomes does not necessarily decreases with more education (Hartog et al, 2007).

However, risk pooling creates the hazard of 'adverse selection', if those most likely to repay opt out in favour of up-front payment. The pool of remaining borrowers then has an above-average risk of default, increasing the risk premium, and providing an even greater incentive for those with low individual risk to opt out. This dynamic is to be avoided.

Higher income taxation (incl. quasi-taxation, such as an income-contingent loan repayment) is expected to decrease the labour supply (Fraja, 2002). In other words, graduate tax (and potentially income-contingent loans too) create a disincentive to work, which should be minimised.

\subsection{Moderately progressive redistribution}

An intensely debated question is whether public funding for $\mathrm{HE}$ implies a reverse subsidy from low-income tax payers to middle-class families, whose children are more likely to benefit (Dabla-Norris and Gradstein, 2004). Empirical evidence remains ambiguous 
(Asplund et al, 2008; Callan et al, 2008), but let us note that a HE cost-sharing instrument should certainly not be prima facie regressive.

Still, private contributions should not be disproportionate to the benefit received. One reason that despite conceptual appeal a pure graduate tax has nowhere been implemented (Asplund et al, 2008) is that high earners would 'repay' a total amount vastly exceeding the cost of their own instruction. Apart from increasing the risk of adverse selection, even if such a significant income transfer is deemed desirable it should be pursued within the scope of an explicit income policy, not implicitly through HE funding (Vandenberghe and Debande, 2007). Indeed, theoretical results suggest that 'pursuing redistributive goals using education policies is bound to have a substantial cost in terms of the sub-optimality of the education policy' (Fraja, 2002).

\subsection{Separation of cost-sharing and marketization}

Cost-sharing potentially affects the nature of HE governance and the relationship between students, their teachers, and HE institutions (HEIs) in ways that might or might not be desired depending on political persuasion. Substantial tuition fees compel potential students to estimate their future income under different enrolment options (Debande, 2004), and possibly to obtain a loan. Institutions may need to introduce new administrative and financial processes if they collect the fees themselves, and if fees are variable, make marketing decisions and assess the relative profitability of different courses.

The justification of tuition fees appeals to economic arguments, namely that they correct incentives for sub-optimal investment in human capital, as well as fiscal ones, namely to relieve pressure on severely constrained public budgets. Moreover, proponents of fees also appeal to the expectation that the accompanying changes in institutional management will improve efficiency (Johnstone, 2004). As paying customers, students can expect and demand better quality of service from HEIs, who become more responsive to student needs, the argument goes.

Actually, a consumerist perspective is far from universal among students even in the UK, most of whom express "mixed, almost ambivalent position on the consumerism of higher education” (Tomlinson 2016, 10, see also Saunders, 2014). Moreover, the student-as- 
consumer approach may fail even on its own terms, with some evidence suggesting it is associated with lower academic performance (Bunce et al. 2016). Students themselves are concerned that it might signal 'lower intellectual merit; which in turn could potentially devalue the social and economic status of their degree’ (Tomlinson 2016, 12).

More fundamental are concerns that commercialising HEIs undermines their ethos and core mission as places of higher learning (McMillan and Cheney, 1996; Teixeira and Koryakina, 2013) and their 'higher purpose' to contribute to social inclusiveness and justice (Schwartz, 2011), and that as hybrid institutions 'neither scientific nor commercial goals can be fulfilled properly’ (Häyrinen-Alestalo and Peltola, 2006, 276).

Given its contentious nature, it is advantageous to disentangle marketization from costsharing as such. Indeed, shifting the balance between public and private contributions can be abstracted from questions regarding the nature of $\mathrm{HE}$ and the roles and expectations of its actors. A fully publicly-funded voucher scheme could in principle induce market competition without increasing effective private contributions (Williams, 1988). Conversely, a key property of DGR is that it shifts part of the resource burden from the public to the private sector without presupposing or determining any particular model of HE governance.

\section{Deferred Graduate Retirement}

DGR does not dominate on all the above criteria, but represents a combination of compromises distinct from those of the alternatives.

\subsection{Definition}

DGR consists of raising the retirement age for graduates. For an individual otherwise eligible for a state pension at age $a$, as an HE graduate this would rise to $a+x$, where a value for $x$ between 1 and 3 years seems plausible. This would be the new pension age for all purposes, including for the calculation of early retirement benefits. The diminished future public liability for pension payments between $a$ and $a+x$ represents a public asset. If HE funding remains constant, a 'pure shift' from public to private funding has occurred.
Commented [PN13]: Reference missing

Commented [14]: Reply to Poulton, Nicholas (05/04/2017, 14:24): "..."

added 
However, if the asset is 'cashed in', the gains must be hypothecated to HE, else we do not have a case of DGR as a HE funding instrument.

This basic principle clearly leaves the actual policy under-determined. For example, will the new pension scheduled be (left-)truncated, or shifted? The implications of such details are mostly financial. Moreover, note that the fact that the system of pension entitlements as a whole is a 'moving target' subject to reform does not create any particular problems. Whatever the formula for pension entitlements or eligibility is at the time - and however complex! - it will use the individual's age as one input, and individuals subject to DGR can be treated as being $x$ years younger than their chronological age.

The concern whether 'the numbers add up' and how the cost-sharing implications of DGR compare to those of tuition fees, is addressed in Section 4. Presently, the modest aim is to introduce the DGR principle in terms of HE policy. In order to simplify the initial exposition without getting side-tracked prematurely, a stylised pension system is assumed, fully public, 'pay as you go', and where retirement timing is driven by statutory age limits. Further below, I discuss some implications of relaxing these assumptions.

\subsection{Distinctiveness}

DGR may appear equivalent to charging fees, but allowing individuals to borrow against their future pension stream, while constraining the use of those funds. However, at the time of university entry, individuals do not yet command any personal future pension entitlements. Only in the aggregate are we confident that their cohort eventually will. As mentioned, theoretically the closest economic equivalent to DGR would be a graduate tax labelled as a higher pension contribution at constant benefits. However, as discussed further below, the behavioural incentives are likely rather different.

In the context pension sustainability and equity, Harper et al (2011) do note the idea of raising the state pension age for graduates, but only as an indirect scheme to approximate their objective of linking the state pension age to healthy life expectancy and/or lifetime earnings. Education is merely taken as a proxy, so their scheme differs from DGR both in purpose and consequence. DGR is independent of whether, for reasons of demographic 
sustainability, the overall ratio of working life and retirement should shift towards the former, as long as the graduate/non-graduate differential is maintained.

What if the eligibility for a state pension derives not (only) from reaching a threshold age, but from having worked a given number of years? If study currently counts towards this tally, then no longer counting it represents a variant of DGR. Whether in addition the age threshold needs to be raised for graduates depends on the relative incidence of the two eligibility criteria among graduate retirees.

The mere existence of an education differential in average de facto retirement age does not by itself serve the same purpose as DGR. In an actuarially fair system, such a behavioural pattern would imply no financial penalty at all on graduates compared to non-graduates. Only a difference in statutory retirement age as the baseline for the calculation of benefits does so.

\subsection{Increasing the private cost share vs. increasing available funding}

For present purposes, distinguishing 'public' and 'private' contributions does not refer to the amount of choice or the location of decision-making power, but purely to the resource burden. As Marginson (2007) has pointed out, this distinction between public and private funding does not predetermine whether HE produces a public and/or private good.

Charging fees 'is not the same as recommending that students, or their families, should bear the costs' (Williams, 1988). A 'fees \& vouchers' scheme would therefore still count as public funding. Conversely, DGR is a form of private contribution, even though the resource reallocation would actually flow from the public purse.

We must further distinguish between private and individual contributions. DGR represents an example of the former, but not the latter, since DGR collectivizes some of the burden. This happens at two different levels: in form of risk-pooling within cohort groups, and riskshifting to the state. 
A key observation is that DGR achieves a shift towards private contributions in purely economic terms independently of whether the future pension savings are monetized. Monetization is only required if DGR is to serve as an instrument of active HE funding. Suppose the alternative is the introduction of tuition fees with a commensurate reduction in public HE funding, motivated by economic considerations of fairness and incentives, rather than as a means to reduce government expenditure. Then DGR would not require monetization in order to achieve the former purpose. By contrast, if the aim is to actively increase HE resources without straining the government budget, this is only achieved by monetizing DGR. To a limited degree such monetization could, however, be achieved passively and indirectly, if the reduced future liabilities support a higher credit rating and more favourable conditions for government borrowing.

\section{A Preliminary Economic Assessment}

A key question is how the net present value (NPV) of the future public savings under DGR compares to the value of tuition fees. This determines both to what extent the relative private and public shares of costs have been shifted, and the additional resources that could potentially be mobilized for current funding. To calculate the NPV, the future value is discounted with a given compounded rate of real interest. The time horizon may be approximated by 50 years, corresponding to university entry at 18 and retirement at 68, for example. Assessing the implications of a graduate tax or delayed income-contingent fees, requires detailed assumptions about incomes, their variance, and their changes with age (to the extent that such schemes practically rely on micro-simulation to be analysed). Similarly, the NPV of DGR depends on a number of parameters. However, the assumptions required for a first approximation are straightforward.

Table 1 shows the years of retirement deferral whose NPV is equivalent to tuition fees under given assumptions regarding: a) the level of fees, b) the interest rate, and c) the value of graduate pensions. The scenarios become less favourable in the rightward and downward directions. The appropriateness and robustness of these assumptions is elaborated in the following. 
With respect to fees, for simplicity I consider EUR 10,000 to represent the stylised 'full cost' fee, close to the OECD average tertiary institution expenditure per student per annum (OECD, 2010). Given that the cost of instruction is typically only two thirds of the overall institution cost (the latter including research spending, for example) (Bevc and Uršič, 2008), this is something of an overestimate. Anyhow, full cost recovery is not sought by most European governments, so DGR would in reality need to cover only between 10 and 50 percent of this to serve as an alternative to tuition fees. For convenience, EUR 3,000 per student per annum, currently exceeded within the EU only in the UK (although a punitive fee for long-term students at this level is under discussion in the Netherlands) is the stylised 'high' level of fees. 'Moderate fees' will be a shorthand for EUR 1,000 per student per annum. A four-year degree is therefore priced at EUR 40,000 (full-cost), EUR 12,000 (high), and EUR 4,000 (moderate) respectively.

With respect to the interest rate, the central scenario of a nominal annual interest rate of 4 percent is in line with existing literature (e.g. Vandenberghe and Debande, 2007). Arguably, this errs on the side of caution. DGR is less attractive to governments experiencing financial crisis, since it does not by itself yield liquid funds (although in any case “cost recovery will not be a "quick fix" for resource shortfalls' (ADB 2009, 21)). The relevant interest rate, for a country with good credit rating, should therefore be towards the low end of the historic range of European government bonds. In this sense, 4 percent is a soundly conservative parameter. This is reflected in the alternative 2 percent scenario. While 4 percent is already conservative for the reason stated, the implications of an exceedingly pessimistic scenario assuming 6 percent nominal interest are also shown.

Finally, we need to consider the value of graduate pensions, Across the EU and OECD, mandatory pensions at retirement on average replace close to 60 percent of the final salary (theoretical gross replacement rate), a figure not expected to change dramatically over the coming decades (EU, 2010; OECD, 2009). Conveniently, at 1 percent inflation, 60 percent is also approximately the inflation adjustment over 50 years. We can therefore express our assumption on the average nominal graduate pension in 50 years' time in terms of the average final graduate salary just before retirement today. For many European countries, the range of EUR 30-40,000 seems plausible, especially where even the average wage is

Commented [PN15]: Please confirm - is this the ref to the Economic Policy Committee?

Commented [16]: Reply to Poulton, Nicholas (05/04/2017, 14:38): "..."

Correct. 
higher (OECD, 2011). The assumption for the inflation rate is conservative. The European Central Bank target rate is closer to 2 percent. Note that higher inflation at a given nominal interest rate works in favour of DGR, because it is the real interest that lowers its value. Assuming 2 percent inflation instead of 1 percent, while maintaining 4 percent nominal interest, would be similar in its effect to lowering the nominal interest rate from 4 to 2.5 .

Table 1: Approximate number of years by which graduate retirement would have to be deferred to substitute for stated annual fees for a four-year-degree

\begin{tabular}{|l|l|l|l|l|l|l|l|}
\hline & & \multicolumn{5}{|c|}{ fees } \\
\hline & & $\begin{array}{l}\text { Moderate } \\
\text { EUR 1,000 } \\
\text { per annum }\end{array}$ & $\begin{array}{l}\text { High } \\
\text { EUR 3,000 } \\
\text { per annum }\end{array}$ & $\begin{array}{l}\text { Full } \\
\text { EUR 10,000 } \\
\text { per annum }\end{array}$ \\
\hline & & $\begin{array}{l}\text { Value of graduate year in the labour force instead of } \\
\text { retirement (nominal EUR) }\end{array}$ & \\
\hline $\begin{array}{l}\text { nominal } \\
\text { interest }\end{array}$ & $\begin{array}{l}\text { NPV of } \\
\text { nominal } \\
\text { EUR } \\
10,000 \\
\text { graduate } \\
\text { pension }\end{array}$ & 40,000 & 30,000 & 40,000 & 30,000 & 40,000 & 30,000 \\
\hline 2 & 3,715 & $<\mathbf{0 . 5}$ & $<\mathbf{0 . 5}$ & $<\mathbf{1}$ & $\mathbf{1}$ & $\mathbf{2 . 5}$ & $\mathbf{3 . 5}$ \\
\hline 4 & 1,407 & $<1$ & $\mathbf{1}$ & $\mathbf{2}$ & $\mathbf{3}$ & $\mathbf{7}$ & $\mathbf{9 . 5}$ \\
\hline 6 & 543 & $\mathbf{2}$ & $\mathbf{2 . 5}$ & $\mathbf{5 . 5}$ & $\mathbf{7 . 5}$ & $\mathbf{1 8}$ & $\mathbf{2 5}$ \\
\hline
\end{tabular}

Evidently, other important factors add to the financial value of DGR, or detract from it. Yet others have indeterminate effects, meaning either its direction depends on the precise 
values of contextual parameters, or that it would require more elaborate modelling to assess.

On the positive side, saved pension payments are only part of the public savings through later retirement. The added value of a longer working life to the economy at large is difficult to estimate. At a minimum, there would be additional income tax revenue. Graduates at the end of their career will typically have above-average wages. Working with the average values for theoretical replacement rates and wages is, in combination, a safe assumption. While the theoretical replacement rates are substantially lower for high wage earners, the absolute pension value (and therefore the value of DGR) will still be higher. For example, a stylised high wage earner with a final salary twice the average will typically experience a gross replacement rate that is about 25 percent lower (EU, 2010). Finally, in comparison with the cost-shifting effect of fees it is very conservative to take these at their face value, as the estimates in Table 1 do. In fact, under typical income-contingent repayment, only a fraction of that value is actually shifted from the public to the private sector (Chowdry et al., 2012) under the tuition fee alternative.

On the negative side, if the additional working years raise the pension claims after the deferral period, then under DGR graduate pensions would be paid for a shorter time, but be slightly higher. Obviously not all graduates would spend the years between their old and new retirement age in employment, receiving unemployment benefits or other transfers under DGR instead of a pension, partly negating the saving in the latter.

Additional costs arise in case DGR is to be monetized to serve as an active HE funding instrument. The transfer to the HE budget may involve substantial transaction costs, especially if the latter is organised at a different level of governance. In Germany, for instance, HE funding comes 'from the budgets of various ministries at federal and state level, from nearly all branches of social security, as well as in form of tax breaks of different kinds' (Gwosc and Schwarzenberger, 2009, 342). Moreover, monetizing the reduction in future pension liabilities relies on the financial markets. How this particular form of asset would be priced is uncertain. In the UK, there were concerns that future graduate tax receipts would only fetch 25 percent of their face value on the financial market (Browne, 2010, 51). The revenue under DGR is only accessed at the very end, so interest 
payments on a bond would themselves need to be financed in the meantime. The long time horizon to maturity by itself is unexceptional, however, and in line with a recent trend towards ‘ultra-long term’ bonds (Hughes and Mackenzie, 2011).

In sum, since some factors would diminish and others inflate the approximate calculation, the latter is neither an obvious over- nor an obvious underestimate. If we accept these figures as reasonable first-order approximations, then with reference to the cells in Table 1 highlighted in the darker shade, we observe the following. In the central scenario, deferring graduate retirement by 2 to 3 years would be broadly comparable to high fees. For moderate fees, this remains true even under pessimistic assumptions. Conversely, even full-cost fees could be approximated under assumptions that are more optimistic, but still well within the realm of what is possible. The latter observation is not to justify such a scenario as plausible, but does show that with respect to lower levels of fees the conclusions are robust.

To be prudent, let us add an additional margin of error, in order to reflect the uncertainty of the estimates, and, in particular, to account for the loss in case DGR is to be monetized as an active funding instrument. If we assume that the NPVs are only half of their above estimates, this doubles the required years of deferral. With respect to the lightly-shaded cells in Table 1, we see that even with a 100 percent margin of error, at most 2 years of deferral would match moderate fees under middle-of-the-road assumptions, or even high fees under more optimistic ones.

\section{Discussion}

The following explores DGR's general implications for HE along the broad criteria outlined in Section 2 and, more speculatively, its promise of policy expedience.

HE access and choice need not be severely affected. DGR promises to be more acceptable to a majority of affected individuals than tuition fees or a graduate tax, both as current prospective students and as future retirees. 
The phenomenon of 'mental accounting' for example, suggests students will not frame deferred retirement in terms of a financial loss, but as 'working longer'. That cost is very far in the future indeed from the perspective of an 18 or 19-year-old, compared to the immediate benefit. Indeed, that prospective students assessment of the costs and benefits of HE is focused on the medium term is highlighted by the fact that 'the expected size of the graduate premium' as a determinant of HE participation can meaningfully be operationalised in terms of income at age 30, instead of lifetime income (Davies et al., 2014). DGR allows 'borrowing' money to invest in HE, but without manifesting itself as tangible, personal debt with a monetary 'sticker price'. Students maintain the freedom to base their choice of degree on criteria other than income generation. Crucially, this is not a matter of 'duping' students into an economically irrational choice, but on the contrary, of avoiding and/or off-setting cognitive biases that have been blamed for marginal entrants being overly reluctant to pursue $\mathrm{HE}$ in the face of fees.

Retirement patterns suggest DGR would also be acceptable to affected individuals as prospective retirees. Across OECD countries, tertiary graduates are already consistently and significantly more likely to remain economically active at higher ages than nongraduates (OECD, 2006). The fact that controlling for cohort trends and partnership status leaves only a modest difference (Brugiavini and Peracchi, 2005) does not invalidate this observation.

Moreover, although well-designed income-contingent fees should, by definition, not constitute an unmanageable burden, repayment overlaps with the 'rush hour of life' when mortgages and family formation place additional strain on the finances of young adults. By contrast, DGR shifts the burden to a time when, towards the end of their career, financial independence is at a peak.

With respect to the insurance characteristics, similar to a pure graduate tax, the amount an individual 'repays' under DGR is not linked to the cost of their own study (unlike a graduate tax, however, there is no risk of vastly disproportionate individual contributions (the so-called 'Mick Jagger effect' [Barr, 2001]), since state pension entitlements top out far below the highest incomes). Instead, a graduate cohort as a group raises the overall cost. The risk premium due to individual income uncertainty is thus pooled across all 
graduates. Through pooling risk within cohorts, as well as shifting onto the state the question of whether to attempt a monetization of the future asset, DGR moderates the burden of increased cost-sharing on individuals.

The risk of adverse selection is underdetermined by the minimal definition of DGR. Given an opt-out option, those participating in DGR might be biased towards a lower likelihood of being economically active and towards lower pensions. Consequently, the amount of deferral would have to be greater than if all graduates without exception are subject to mandatory DGR. However, graduates from private HEIs not receiving public funds would have to be subject to deferred retirement regardless. Assuming this group is more privileged on average, this would constitute an additional redistributive measure. Otherwise, if DGR only applied to graduates from public HEIs, the adverse selection problem would not only rear its head again, but come hand in hand with increasing social stratification between public and private HEIs.

DGR's distributional implications depend on how the issue is framed. In terms of transfers, there is no effective resource flow from non-graduates to graduates that would make the scheme evidently inequitable. However, in terms of income distributions with and without DGR, its face-value effect is actually regressive. This is because deferring their retirement will increase the life-time income of graduates compared to non-graduates. This ignores the value of the free time, however. If current retirement behaviour reflects their preferences for income versus free time, then imposing DGR may imply a net loss of utility for graduates, even in the face of a higher total income. Ultimately, absent detailed knowledge of preferences, the distributional implications of DGR are undetermined.

What is clear is that the private contribution under DGR cannot be borne by privileged students' parents on their behalf. This property increases the distributional merit, and potentially makes the policy more attractive in settings, e.g. Scandinavia, where parental support is traditionally discouraged.

A consequence of DGR that ought to appeal to legislators, planners and administrators is increased freedom in designing policy and flexibility in implementing it. Under DGR, the core effect of shifting the resource burden is isolated from other effects on the HE sector. 
As long as the only action taken is to increase the statutory retirement age for new graduates, the only tangible change is that future public liabilities per graduate have diminished. A significant share of the resource burden of $\mathrm{HE}$ is thus shifted from the public onto private shoulders, but without directly affecting the HE system or educational dynamics in any way. At this stage, current flows of public payments to HEIs have neither increased nor decreased, and no action whatsoever is required of either prospective students or HEIs. From their perspective, the shift in resourced burden is achieved 'at the stroke of a pen'.

Moreover, because the private contribution under DGR is postponed by a long time, future governments may renew their commitment to $\mathrm{HE}$ as a public good and waive the retirement deferral. Unlike fees or graduate taxes that would be difficult to reimburse decades later, DGR constitutes a shift from public to private funding that remains reversible for some time, and should therefore be easier to enact. This does, of course, come at the cost that if monetization already occurred, this debt would have to be 'bought back'. Otherwise, similar to graduate taxes, the fact they 'may be abandoned tomorrow by another government [...] seriously diminishes the[ir] marketable present value' (Johnstone, 2000, 6). However, this may be seen as a challenge to design appropriate commitment devices rather than a fundamental objection.

If monetized and the savings redirected to actively increase HE funding, DGR does not directly contribute to the sustainability of the pension system. As a pure cost-sharing instrument without monetization, the pension system would benefit, however. Either way, DGR would have the side-effect of raising the effective average retirement age, thereby promote a social norm for later retirement. In addition, even if the savings are diverted, the additional receipts resulting from graduate's additional working years need not be.

Later retirement for graduates is likely to appear almost self-evidently fair to the general public; after all, graduates also enter the labour market later. Arguably, serious study constitutes unpaid, but nevertheless economically productive, work. Also, graduates may not spend so much less time in working if they suffer less and shorter unemployment. Nevertheless, in terms of political feasibility, it is ultimately perceived fairness that matters. 
The above caveats are unlikely to be able to dent the persuasiveness of the simple formula ‘enter later, exit later’.

Differentiated statutory retirement ages are not intrinsically socially unacceptable. Differentiation by gender is common, but there are also examples of differentiation according to life choices. In the Czech Republic, the retirement age for women is contingent on the number of children (OECD, 2009). In extreme cases, changing the retirement age for specific occupations may serve purely as an instrument of manpower planning (Ganjapure, 2010). A variable pension age has already been injected into the policy debate in the context of pension sustainability (Harper et al, 2011), even contingent on individual factors much more speculative, such as healthy life expectancy. Anyhow, the deferral by one to three years implied by DGR is considerably less than the existing variation in state pension age between OECD members.

An important question is whether the scheme can be actively subverted. The first concern relates to mobility, that 'students could vote with their feet, i.e. study in those countries where their financial participation is the most limited and work afterwards where the returns to education are the highest' (Guille, 2002, 429). Even without DGR, ‘a [European] harmonisation of funding policies of higher education seems necessary', therefore (Guille, 2002, 429). While Brooks and Waters (2013), for instance, see some mobility motivated by tuition-fee differentials, there is little evidence of large-scale migration flows induced by fee avoidance, even between areas where mobility barriers are particularly low (Wakeling and Jefferies, 2013). If anything, some countries exhibiting the least ‘affordability’ of HE (Vossensteyn, 1999) have among the highest shares of foreign EU students, demonstrating that other aspects (language, perceived quality, etc.) outweigh cost concerns. Indeed, 'those with most incentive to escape high-cost tuition fee regimes may also be least able (or willing) to be geographically mobile' (Wakeling and Jefferies 2013, p. 18). Anyhow, the share of migrants among the total graduate labour force remains relatively small, and by the second half of this century, some kind of 'common pension area' in the EU may be expected. Indeed, recent EU negotiations on harmonising economic governance have explicitly included the subject of pensions (Der Spiegel, 2011). In sum, there is little evidence that justifies fears of a mass-phenomenon of students circumventing 
DGR either by studying elsewhere, or by migrating immediately following graduation. But once they have worked in the relevant jurisdiction for some time and accrued pension claims, DGR is actually more difficult to avoid than delayed fee repayment or a graduate tax, because it is easier to withhold a benefit than to collect a payment.

The second 'free riding' concern is the theoretical moral hazard of students and employers colluding to fill graduate jobs with individuals who completed their studies but never officially graduated. They would receive salaries slightly lower than certified graduates, making the scheme lucrative for both parties. However, this is unrealistic on a grand scale. The tactic fails for law, medicine, architecture, engineering, and other regulated professions. It would preclude public sector employment. Moreover, the centrality of certification arises almost inevitably from the systemic logic of any formal education system (Green, 1980). In any case, if the risk of 'free riding' is seen as significant, an alternative would be to defer the retirement age by a given number of months per semester of HE enrolment, since presumably enrolment cannot be avoided in order to benefit from the course. Nor can the repayment be evaded by deliberately failing to reach the retirement threshold, since the scheme assumes early retirement benefits will be downscaled accordingly.

A number of pertinent questions would require formal economic modelling that is beyond the scope of the present expository article. For example, this includes the question whether, subject to real-life credit constraints and uncertainty, the DGR scheme creates incentives for over or under-investment in $\mathrm{HE}$ at the individual or public level if retirement decisions are endogenous. A key concern with graduate taxes and income-contingent loan is the extent to which they depress the labour supply. Again, a formal analysis of this question with respect to DGR is beyond the present scope. However, unlike the former two schemes, earning a higher income is not directly penalised (and thereby disincentivised).

\section{Conclusion}

Clearly, despite combining many attractive characteristics, DGR does not dominate all alternatives on all criteria, much less in all settings. Nonetheless, DGR offers a genuinely 
novel combination of characteristics and therefore potentially presents a true addition to the existing policy toolbox. This by itself is a relevant contribution, as the tools currently available haven proven too limited to create a broad consensus among the different stakeholders and political camps.

In introducing a novel scheme, it seems necessary to begin with a comprehensive general discussion in order to establish the principle, without focusing prematurely on specific parameter values. An obvious next step is to fully quantify the factors discussed in Section 4 based on empirical data and forecasts for specific countries, to arrive at a more robust estimate of the net public saving associated with each additional graduate year in the labour force. Next, including DGR within a formal life-cycle model with endogenous decisions on human capital investment, labour force participation, and retirement will be required to deepen our understanding of its implications.

Many important questions remain to be addressed, and the present contribution has, at best, provided a first 'inventory of issues'. However, none of the most obvious concerns appear to deal a death-blow to the idea. Indeed, the concept of a 'pure' graduate tax continues to be discussed despite general agreement that it is infeasible or even undesirable in practice. Income-contingent deferred fee schemes are not only debated, but even implemented, despite recognition of the risk that they may well fail to actually generate any meaningful net revenue once interest-subsidies, forgiveness-clauses, default, and administrative costs are taken into account. Similarly, the proposed scheme of Deferred Graduate Retirement does not need to be perfect to merit further investigation at least. By forcing the debate outside the settled groove, such investigations may benefit our understanding of the policy trade-offs involved even if DGR itself were ultimately rejected as a mere thought experiment. In light of the unresolved challenge that 'equity of participation in higher education [...] has been solved by no nation, rich or poor, capitalist or socialist' (Heyneman, 1995, 560), broadening the debate is necessary, especially in ways that potentially create common ground by disentangling the question of economic burdens and incentives at the individual level from institutional commercialization. 


\section{References}

Altbach, P.G., Reisberg, L. and Rumbley, L.E (2009) Trends in global higher education: Tracking an academic revolution, Paris: UNESCO.

Asian Development Bank (ADB) (2009) Good Practice in Cost Sharing and Financing in Higher Education, Manilla: ADB.

Asplund, R., Adbelkarim, O.B. and Skalli, A. (2008) 'An equity perspective on access to, enrolment in and finance of tertiary education', Education Economics 16(3): 261-274.

Barr, N. (2004) 'Higher education funding', Oxford Review of Economic Policy 20(2): 264-283.

Barr, N.A. (2001) The welfare state as piggy bank: Information, risk, uncertainty, and the role of the state, New York: Oxford University Press.

Bevc, M. and Uršič, S. (2008) 'Relations between funding, equity, and efficiency of higher education', Education Economics 16(3): 229-244.

Biffl, G. and Issac, J. (2002) 'Should Higher Education Students Pay Tuition Fees?', European Journal of Education 37(4): 433-455.

Brooks, R. \& Waters, J. (2011) 'Fees, funding and overseas study: mobile UK students and educational inequalities', Sociological Research Online 16(2).

Browne, J. (2010) Securing a sustainable future for higher education: An Independent Review of Higher Education and Student Finance in England, London, UK: Department for Business, Innovation \& Skills.

Brugiavini, A. and Peracchi, F. (2005) 'The length of working lives in Europe', Journal of the European Economic Association 3(2-3): 477-486.

Bunce, L., Baird, A. and Jones. S.E. (2016) 'The Student-as-Consumer Approach in Higher Education and Its Effects on Academic Performance', Studies in Higher Education, Published online 14 January 2016, doi:10.1080/03075079.2015.1127908. 
Callan, T., Smeeding, T. and Tsakloglou, P. (2008) 'Short-run distributional effects of public education transfers to tertiary education students in seven European countries', Education Economics 16(3): 275-288.

Callender, C. \& Jackson, J. (2005) 'Does fear of debt deter students from higher education?', Journal of Social Policy 34(4): 509-540.

Callender, C. \& Jackson, J. (2008) 'Does the fear of debt constrain choice of university and subject of study?', Studies in Higher Education 33(4): 405-429.

Chowdry, H., Dearden, L., Goodman, A. and Wenchao, J. (2012) 'The Distributional Impact of the 2012-13 Higher Education Funding Reforms in England', Fiscal Studies 33(2): 211-236.

Dabla-Norris, E. and M. Gradstein (2004) The Distributional Bias of public education: causes and consequences, Washington, DC: International Monetary Fund.

Davies, P., Mangan, J. and Hughes, A. (2009) 'Participation, financial support and the marginal student', Higher Education 58(2): 193-204.

Davies, P., Qiu, T. and Davies, N.M. (2014) ‘Cultural and Human Capital, Information and Higher Education Choices', Journal of Education Policy 29(6): 804-825.

Debande, O. (2004) 'A Review of Instruments for Student Loans in Tertiary Education', European Journal of Education 39(2): 161-190.

Der Spiegel (2011) Merkel boxt Euro-Wirtschaftsregierung durch [Merkel Rams Through Establishment of European Economic Council], Spiegel Online - 4 February 2011

\section{European Union (Economic Policy Committee [Ageing Working Group], Social Protection} Committee [Indicators Sub-Group] and Commission services [DG for Economic and Financial Affairs and DG Employment, Social Affairs and Equal Opportunities]) (2010). 'Future adequacy of pensions measured by Theoretical Replacement Rates'. In: Joint Report on Pensions: Progress and key challenges in the delivery of adequate and sustainable pensions in Europe. 71. European Union. Chap. Annex 5.
Commented [PN19]: Not cited in text - please delete if not cited.

Commented [20]: Reply to Poulton, Nicholas (05/04/2017, 15:15): "..."

Done

Commented [PN21]: Please provide English translation

Commented [22]: Reply to Poulton, Nicholas

(05/04/2017, 15:18): "..."

done 
Fraja, G.D. (2002) 'The design of optimal education policies', Review of Economic Studies 69(2): 437-466.

Ganjapure, V. (2010) 'Govt may raise principals’ retirement age to 62', The Times of India, 26 September.

Gerard, M. and Vandenberghe, V. (2007) 'Introduction: Economics of Higher Education’, Education Economics 15(4): 383-384.

Green, T.F. (1980) Predicting the Behaviour of the Educational System, Syracuse, NY: Syracuse University Press.

Guille, M. (2002) ‘Student Loans: a solution for Europe?’, European Journal of Education 37(4): 417-431.

Gwosc, C. and Schwarzenberger, A. (2009) 'Die Finanzierung der Hochschulbildung in Deutschland' [The Financing of Higher Education in Germany], Wirtschaftsdienst 89(5):

\section{4-342.}

Harper, S., Howse, K. and Baxter, S. (2011) Living longer and prospering? Designing an adequate, sustainable and equitable UK state pension system, Oxford: Oxford Institute of Ageing.

Harrison, N. (2011) 'Have the changes introduced by the 2004 Higher Education Act made higher education admissions in England wider and fairer?', Journal of Education Policy 26(3): 449-468.

Hartog, J., van Ophem, H. and Bajdechi, S.M. (2007) 'Simulating the risk of investment in human capital', Education Economics 15(3): 259-275.

Häyrinen-Alestalo, M. and Peltola, U. (2006) 'The Problem of a Market-oriented University’, Higher Education 52(2): 251-281.

Heyneman, S.P. (1995) 'Economics of education: Disappointments and potential', Prospects 25(4): 557-583.
Commented [PN23]: Please give English translation in square brackets [ ]

Commented [24]: Reply to Poulton, Nicholas (05/04/2017, 15:22): "..."

done
Commented [PN25]: Not cited in text - to be deleted if not used.

Commented [26]: Reply to Poulton, Nicholas (05/04/2017, 15:25): "..."

It was included as a "container" reference for two chapters from it that are cited, but I have deleted it now. 
Hossler, D., Lund, J.P., Ramin, J., Westfall, S. and Irish, S (1997) 'State funding for higher education: The Sisyphean task', Journal of Higher Education 68(2): 160-190.

Hughes, J. and Mackenzie, M. (2011) ‘US asked to follow ultra-long bond trend’, Financial Times Online Edition, 3 February.

Hutchings, M. (2003) 'Financial barriers to participation', In L. Archer, M. Hutchings \& A. Ross (Eds) Higher education and social class: issues of exclusion and inclusion (London \& New York, RoutldegeFalmer), 155-174.

Johnstone, D. (2004). 'The economics and politics of cost sharing in higher education: comparative perspectives', Economics of Education Review 23(4): 403-410.

Johnstone, D.B. (2000) Student loans in international perspective: promises and failures,myths and partial truths, Buffalo, NY.: Center for Comparative and Global Studies in Education, Graduate School of Education, State University of New York at Buffalo.

McMillan, J., and G. Cheney. (1996) 'The Student as Consumer: The Implications and Limitations of a Metaphor', Communication Education 45(1): 1-15.

Marcucci, P. (2013) 'The Politics of Student Funding Policies From a Comparative Perspective.' In Heller, D. E, and C. Callender (Eds) Student Financing of Higher Education. Routledge.

Marginson, S. (2007) 'The public/private divide in higher education: A global revision', Higher Education 53(3): 307-333.

Neill, C. (2009) 'Tuition fees and the demand for university places', Economics of Education Review 28(5): 561-570.

OECD (2006) Live longer, work longer, Paris: OECD.

OECD (2009) Pensions at a Glance 2009: Retirement-Income Systems in OECD

Countries, Paris: OECD.

OECD (2010) Education at a Glance 2010: OECD Indicators, Paris: OECD.

OECD (2011) Pension Database, http://stats.oecd.org/. 
Saunders, D.B. (2014) 'They Do Not Buy It: Exploring the Extent to Which Entering First-

Year Students View Themselves as Customers', Journal of Marketing for Higher Education 25(1): 5-28.

Scott-Clayton, J. (2013) ‘Information Constraints and Financial Aid Policy.’ In Heller, D. E, and C. Callender (Eds) Student Financing of Higher Education. Routledge.

Schwartz, S. (2011) The Higher Purpose. Times Higher Education, 1 January.

Shen, H. and Ziderman, A. (May 2008) 'Student loans repayment and recovery: international comparisons', Higher Education 57(3): 315-333.

Teixeira, P. and Koryakina, T. (2013) 'Funding Reforms and Revenue Diversification Patterns, Challenges and Rhetoric', Studies in Higher Education 38(2): 174-191.

Tilak, J. B. G. (2009) 'Higher education: a public good or a commodity for trade?', Prospects 38(4): 449-466.

Tomlinson, M. (2016) 'Student Perceptions of Themselves as 'Consumers' of Higher Education', British Journal of Sociology of Education, Published online 4 January 2016 doi:10.1080/01425692.2015.1113856.

Usher, T. (2010) The Role of Finance in the Decision-Making of Higher Education Applicants and Students, BIS Research Paper No. 9, Brighton: Institute for Employment Studies.

Vandenberghe, V. and Debande, O. (2007) 'Deferred and Income-Contingent Tuition Fees: an empirical assessment using Belgian, German and UK data', Education Economics 15(4): 421-440.

Vossensteyn, J.J. (1999) 'Where in Europe would people like to study? The affordability of higher education in nine Western European countries', Higher Education 37(2): 159176.

Wakeling, P., and Jefferies, K. (2013) 'The Effect of Tuition Fees on Student Mobility: the UK and Ireland as a Natural Experiment', British Educational Research Journal 39(3): 491-513. 
Whitty, G., Hayton, A. and Tang, S. (2015) 'Who You Know, What You Know and Knowing the Ropes: a Review of Evidence About Access to Higher Education Institutions in England', Review of Education 3(1): 27-67.

Williams, G. (1988) 'The Debate about Funding Mechanisms', Oxford Review of Education 14(1): 59-68.

Williams, J. (2014) 'A Critical Exploration of Changing Definitions of Public Good in Relation to Higher Education', Studies in Higher Education 41(4): 619-30. 